\title{
A comparative study between small dose dexamethasone, tropisteron, metoclopramide and normal saline in reducing nausea and vomiting after laparoscopic cholecystectomy
}

Accepted: $26 / 4 / 2012$

\begin{abstract}
Background and objective: Nausea and vomiting are among the most common distressing complications encountered by patients postoperatively. The aim of this study is to evaluate the prophylactic effect of small dose of dexamethasone $(5 \mathrm{mg})$ on postoperative nausea and vomiting (PONV) after laparoscopic cholecystectomy (LC).
\end{abstract}

Methods: A prospective double blind placebo controlled study of 160 patients who underwent elective LC at Rizgary Teaching and Hawler Private Hospitals in Erbil, Kurdistan in a period between Jan 2009 and Dec 2009. Preoperatively the patients were allocated randomly to one of the four groups ( $n=40$ each).

1. The dexamethasone group received dexamethasone $5 \mathrm{mg}$.

2. The metoclopramide group received metoclopramide $10 \mathrm{mg}$.

3 . The tropisetron group received tropisetron $2 \mathrm{mg}$.

4. The placebo group received normal saline $2 \mathrm{ml}$.

Results: Both the dexamethasone and tropisetron groups were significantly different from the placebo group in the incidence of nausea and vomiting. The differences between the dexamethasone and tropisetron groups were not significant $(\mathrm{P}=0.799)$.

Conclusion: : prophylactic IV dexamethasone $5 \mathrm{mg}$ significantly reduces the incidence of PONV in patients undergoing LC.

Keywords: Postoperative, nausea, vomiting, laparoscopy

\section{Introduction}

Laparoscopic surgery provides benefits to patients, including tremendous faster recovery, shorter hospital stay and prompt return to normal activities 1. It has decreased the morbidity associated with cholecystectomy and has become a routine procedure for symptomatic Cholelithiasis 2,3 . despite the minimally invasive nature of laparoscopy, high incidence of postoperative nausea and vomiting (PONV) remains a major cause for morbidity ${ }^{1}$. A frequent incidence of PONV (53\%-72\%) has been reported ${ }^{4-7}$. PONV is among the most common distressing side effects encountered by patients following anesthesia and surgical procedures, Kapur described PONV as the 'big, little problem ${ }^{8}$ a description that still applies. Until recently, not enough attention was paid to PONV. As a result, it was considered by patients, and often unfortunately, also by doctors, as unnecessary and natural consequence of anesthesia and surgery ${ }^{9}$. Glucocorticoids are well known for their analgesic, antiinflammatory, immune-modulating, and antiemetic effects, although the mechanisms by which glucocorticoids exert their action are far from clarified ${ }^{10}$. Several randomized, clinical trials in many different major and minor surgical procedures have been conducted to examine the effects of a perioperative single-dose glucocorticoid administration on surgical outcome ${ }^{11}$. The overall results on postoperative outcome

*Department of Surgery, Rizgary Teaching Hospital, Erbil, Iraq.

$* *$ Department of Surgery, College of Medicine, Hawler Medical University, Erbil, Iraq. 
have either been positive in favor of the glucocorticoid group or without differences between study groups, with PONV and pain as outcome parameters most significantly improved ${ }^{11-13}$. The aim of this study is to evaluate the prophylactic effect of small dose of dexamethasone $(5 \mathrm{mg})$ on postoperative nausea and vomiting in patients undergoing laparoscopic cholecystectomy and comparing these effects with tropisetron, metoclopramide and normal saline.

\section{Methods}

This is a prospective double blind placebo controlled study of 160 patients who underwent elective LC at Rizgary Teaching and Hawler Private Hospitals in Erbil, Kurdistan, Iraq in a period between Jan 2009 and Dec 2009. Only patients with ASA physical status I or II included in the study. Patients with a history of PONV, motion sickness, gastrointestinal disorders, pregnant or lactating patients, or who had received an antiemetic drug within $24 \mathrm{hrs}$ before surgery were excluded from the study. Informed consents were taken from all patients. The study approved by Local Ethical comity. Preoperatively the patients were allocated randomly to one of the four groups ( $n=40$ each).

1.The dexamethasone group received dexamethasone $5 \mathrm{mg}$.

2.The metoclopramide group received metoclopramide $10 \mathrm{mg}$.

3.The tropisetron group received tropisetron $2 \mathrm{mg}$.

4.The placebo group received normal saline $2 \mathrm{ml}$.

the study medications were prepared by anesthesia nurses in identical 2-ml syringes. The drugs were given immediately after the induction of anesthesia intravenously. Postoperative analgesia was provided by either tramadol $100 \mathrm{mg}$ or diclofenac $75 \mathrm{mg}$ intramuscularly (IM). The patients' demographics and the duration of anesthesia, surgery, and $\mathrm{CO}_{2}$ insufflations were recorded. Postoperatively data collected about presence of nausea, vomiting, and rescue antiemetic. The condition regarded as complete response when there was no nausea, no vomiting, and no antiemetic medication during $24 \mathrm{~h}$ postoperatively. The number of vomiting episodes was registered. Rescue antiemetic was given in the form of metoclopramide $10 \mathrm{mg}$ IV for those patients who experienced vomiting. All patients reexamined after 10 days postoperatively to see if there is any complication. The data analyzed statistically by Microsoft Excel and internet(http:// www.graphpad.com). Chi-square test used for $p$ values calculation.

\section{Results}

The patient demographics (e.g. age, sex, and weight) and the duration of anesthesia, surgery, and $\mathrm{CO}_{2}$ insufflations were similar among the groups Table 1 . The overall incidence of PONV during the first $24 \mathrm{~h}$ after surgery was $25 \%$ with dexamethasone, $27.5 \%$ with tropisetron, $37.5 \%$ with metoclopramide and $47.5 \%$ with placebo groups Table 2. Both the dexamethasone and tropisetron groups were significantly different from the placebo group in the following variables: the total incidence of nausea and vomiting, more than 3 vomiting episodes, the proportions of patients requiring rescue antiemetic, and the incidence of complete responses Table 2. The differences between the dexamethasone and tropisetron groups were not significant $(P=0.799)$. Of these patients, $12.5 \%$ in dexamethasone group, $15 \%$ in tropisetron group, $17.5 \%$ in metoclopramide group, and $37.5 \%$ in placebo group were required rescue antiemetic Table 2 . No clinically serious adverse effects of the study drugs observed. 
Table 1: The patients' demographics and operative characteristics.

\begin{tabular}{|c|c|c|c|c|}
\hline & $\begin{array}{l}\text { Dexamethasone } \\
(n=40)\end{array}$ & $\begin{array}{l}\text { Metoclopramide } \\
(\mathrm{n}=40)\end{array}$ & $\begin{array}{l}\text { Tropisetron } \\
(n=40)\end{array}$ & $\begin{array}{l}\text { Placebo } \\
(n=40)\end{array}$ \\
\hline Mean age (Yr) & 50 & 48 & 47 & 51 \\
\hline $\operatorname{Sex}(M / F)$ & $12 / 28$ & $14 / 26$ & $11 / 29$ & $10 / 30$ \\
\hline $\begin{array}{l}\text { Mean Weight } \\
(\mathrm{kg})\end{array}$ & 62 & 60 & 59 & 63 \\
\hline $\begin{array}{l}\text { Mean Duration of } \\
\text { anesthesia (min.) } \\
\text { Mean Duration of } \\
\text { operation (min.) }\end{array}$ & 45 & 45 & 47 & 48 \\
\hline $\begin{array}{l}\text { Mean Duration of } \\
\mathrm{CO}_{2} \text { insufflations } \\
\text { (min.) }\end{array}$ & 26 & 25 & 23 & 26 \\
\hline Diclofenac & 15 & 16 & 18 & 19 \\
\hline Tramadol & 12 & 13 & 15 & 17 \\
\hline
\end{tabular}

Table 2: The Evaluation of Postoperative Nausea and vomiting during the first $24 \mathrm{~h}$ postoperatively.

\begin{tabular}{|c|c|c|c|c|c|}
\hline Variable & & $\begin{array}{l}\text { Dexamethasone } \\
\quad(5 \mathrm{mg})\end{array}$ & $\begin{array}{l}\text { Tropisetron } \\
(2 \mathrm{mg})\end{array}$ & $\begin{array}{l}\text { Metoclopramide } \\
(10 \mathrm{mg})\end{array}$ & $\begin{array}{l}\text { Placebo } \\
(2 \mathrm{ml})\end{array}$ \\
\hline Nausea & & $6(15 \%)$ & $6(15 \%)$ & $8(20 \%)$ & $12(30 \%)$ \\
\hline Vomiting & & $4(10 \%)$ & $5(12.5 \%)$ & $5(12.5 \%)$ & $7(17.5 \%)$ \\
\hline \multirow{2}{*}{$\begin{array}{l}\text { Total } \\
\text { (Nausea+ } \\
\text { Vomiting) }\end{array}$} & $\begin{array}{l}\mathrm{N}(\%) \\
\mathrm{P} \text { value }\end{array}$ & $10(25 \%)$ & $11(27.5 \%)$ & $13(32.5 \%)$ & $19(47.5 \%)$ \\
\hline & & 0.036 & 0.064 & 0.170 & \\
\hline \multirow[t]{2}{*}{$\begin{array}{l}\text { Vomiting } \\
\text { episodes }\end{array}$} & $\begin{array}{l}0-3 \\
\text { episodes }\end{array}$ & $3(7.5 \%)$ & $3(7.5 \%)$ & $3(5 \%)$ & $3(7.5 \%)$ \\
\hline & $\begin{array}{l}>3 \\
\text { episodes }\end{array}$ & $1(2.5 \%)$ & $2(5 \%)$ & $4(7.5 \%)$ & $4(10 \%)$ \\
\hline \multirow{2}{*}{$\begin{array}{l}\text { Rescue } \\
\text { Antiemetic }\end{array}$} & $\mathrm{N}(\%)$ & $5(12.5 \%)$ & $6(15 \%)$ & $7(17.5 \%)$ & $15(37.5 \%)$ \\
\hline & $P$ value & 0.009 & 0.022 & 0.045 & \\
\hline \multirow{2}{*}{$\begin{array}{l}\text { Complete } \\
\text { Responses }\end{array}$} & $\mathrm{N}(\%)$ & $30(75 \%)$ & $29(72.5 \%)$ & $27(67.5 \%)$ & $21(52.5 \%)$ \\
\hline & & 0.01 & 0.02 & 0.07 & \\
\hline
\end{tabular}




\section{Discussion}

Several studies have demonstrated dexamethasone's efficacy in the prevention of nausea and vomiting associated with chemotherapy ${ }^{14-17}$. Dexamethasone also prevents PONV in patients undergoing hysterectomy, tonsillectomy, and thyroidectomy ${ }^{18}$ -20 . The dose often used is 8 to $10 \mathrm{mg}^{18}$, but the minimal effective dose is $5 \mathrm{mg}$ in patients undergoing thyroidectomy ${ }^{19}$. Dexamethasone $8 \mathrm{mg}$ is also effective in reducing the incidence of PONV after LC ${ }^{5}$. We further found that dexamethasone $5 \mathrm{mg}$ is also effective for this purpose. Tropisetron, a serotonin subtype 3 receptor antagonist, is primarily used in the prevention of chemotherapy-related nausea and vomiting ${ }^{21-}$ ${ }^{22}$. It has also been applied to the prophylaxis of PONV ${ }^{23-25}$. Although tropisetron 2 and $5 \mathrm{mg}$ frequently used in the prevention of PONV. Many studies proved that $2 \mathrm{mg}$ Tropisetron enough for this purpose ${ }^{23-26}$. Our study also showed this fact. Metoclopramide, a central dopaminergic $D_{2}$ receptor antagonist and a prokinetic drug, was found by some authors to be an efficient agent in the prevention of PONV when given in $10 \mathrm{mg}^{27-29}$ or $20 \mathrm{mg}$ dose $\mathrm{e}^{29}$ where as others found that it is inefficient in preventing PONV ${ }^{30-32}$. In our study metoclopramide in a dose of $10 \mathrm{mg}$ proved to be a poor preoperative prophylactic antiemetic agent. We found no significant reduction of PONV on comparing metoclopramide with placebo. In this study dexamethasone $5 \mathrm{mg}$ was as effective as tropisetron $2 \mathrm{mg}$ and was more effective than placebo for this purpose. Near same results were found in other studies ${ }^{17,33}$. In our locality 1 ampule dexamethasone $(5 \mathrm{mg})$ costs 1000 ID while 1 ampule tropisetron (2 mg) costs 22000 ID. Therefore, dexamethasone $5 \mathrm{mg}$ is a more reasonable choice than tropisetron 2 $\mathrm{mg}$ for the prevention of PONV. No impaired wound healing, postoperative Infetion were associated with the use of dexamethasone in this study, same as seen in the studies done by (Wang $\mathrm{J}$ et al) ${ }^{34},\left(\right.$ Feo C et al) ${ }^{35}$.

\section{Conclusions}

Prophylactic IV dexamethasone $5 \mathrm{mg}$ significantly reduces the incidence of PONV in patients undergoing LC. At this dose, dexamethasone is as effective as tropisetron 2 $\mathrm{mg}$ and is more effective than metoclopramide and placebo.

\section{References}

1. Gupta P, Khanna J, Mitramustafi A, Bhartia V. Role of preoperative Dexamethasone as prophylaxis for postoperative nausea and vomiting in laparoscopic surgery, Journal of Minimal Access Surgery 2006;3(2): 12-15.

2. Begos DG, Modlin IM. Laparoscopic cholecystectomy: from gimmick to gold standard. J clin Gastroenterol 1994;19:325-30.

3. Sandor J, Sandor A, Zaborszky A. Why laparoscopic cholecystectomy today? Surg Today 1996; 26:556-60.

4. Naguib M, Bakry AKEI, Khoshim MHB. Prophylactic antiemetic therapy with ondansetron, Tropisetron, granisetron and Metoclopramide in patients undergoing laparoscopic cholecystectomy: a randomized, double-blind comparison with placebo. Can J Anaesth 1996; 43: 226-31.

5. Jokela R, Koivuranta M. Tropisetron or droperidol in the prevention of postoperative nausea and vomiting. Acta Anaesthesiol Scand 1999; 43: 64550.

6. Wang JJ, Ho St, Liu YH. Dexamethasone reduces nausea and vomiting after laparoscopic cholecystectomy. Br J Anaesth 1999; 83: 772-5.

7. Fujii Y, Saitoh Y, Tanaka. Ramosetron vs granisetron for the prevention of postoperative nausea and vomiting after laparoscopic cholecystectomy. Can J Anaesth 1999; 46: 991-3.

8. Kapur PA. The big, little problem. Anaesth Analg 1991; 72:243-5.

9. Leksowski K, Peryga P, Szyca R. Ondansetron, Metoclopramide, Dexamethasone, and their combinations compared for the prevention of postoperative nausea and vomiting in patients undergoing laparoscopic cholecystectomy: A prospective randomized study, Surg Endosc 2006;20:878-882.

10. Sapolsky RM, Romero LM, Munck AU. How do glucocorticoids influence stress responses? Integrating permissive, suppressive, stimulatory, and preparative actions. Endocr Rev. 2000;21:55-89.

11. Holte $\mathrm{K}$, Kehlet $\mathrm{H}$. Perioperative single dose glucocorticoid administration-Pathophysiological effects and clinical implications. J Am Coll Surg. 2000;195:186-712.

12. Henzi I, Walder B, Tramer MR. Dexamethasone for the prevention of postoperative nausea and vomiting: a quantitative systematic review. Anesth Analg. 2000;90:186-194. 
13. Fujii Y, Saitoh Y, Tanaka H. Granisetron/ dexamethasone combination for the prevention of postoperative nausea and vomiting after laparoscopic cholecystectomy. Eur J Anaesthesiol. 2000;17:64-68.

14. The Italian Group for Antiemetic Research. Dexamethasone, granisetron, or both for the prevention of nausea and vomiting during chemotherapy for cancer: N Engl J Med 1995; 332: 1-5.

15. The Italian Group for Antiemetic Research. Ondansetron versus metoclopramide, both combined with dexamethasone, in the prevention of cisplatininduced delayed emesis: the Italian Group for Antiemetic Research. J Clin Oncol 1997; 15: 124-30.

16. Sehine I, Nishiwaki Y, Kakinuma R. Phase II study of high-dose dexamethasone-based association in acute and delayed high-dose cisplatininduced emesis: study 9413. Br J Cancer 1997; 76 : 90-2.

17. Jeng-Chai, Ja-Ping Shieh, Chao-Shun Tang, Jann-Inn Tzeng, Koung-Shing Chu and Jhi-Joung Wang. Low dose Dexamethasone effectively prevents postoperative nausea and vomiting after ambulatory laparoscopic surgery, Canadian Journal of Anesthesia 2001; 48(10):973-977.

18. Henzi I, Walder B, Tramer M. Dexamethasone for the prevention of postoperative nausea and vomiting: a quantitative systemic review. Anaesth Analg 2000; 90: 186-94.

19. Wang JJ, Ho ST, Lee SC. The use of Dexamethasone for preventing postoperative nausea and vomiting in females undergoing thyroidectomy: a dose-ranging study. Anaesth Analg 2000;91:1404 -7 .

20. www.novartis.com.au/PI PDF/nav.pdf

21. Simpson K, Spencer CM, McClellan KJ. Tropisetron: an update of its use in the prevention of chemotherapy-induced nausea and vomiting. Drugs 2000; 59:1297-315.

22. Gregory RE, Ettinger DS. 5-HT3 receptor antagonists for the prevention of chemotherapy-induced nausea and vomiting. Drugs 1998; 55: 173-89.

23. Alon E, Buchser E, Herrera E. Tropisetron for treating established postoperative nausea and vomiting: a randomized, double-blind, placebocontrolled study. Anaesth analg 1998; 86:617-23.

24. Cunningham RS. 5-HT3 receptor antagonists: a review of pharmacology and clinical efficacy.

25. Purhonen S, Kauko M, Koski E. Comparison of Tropisetron, droperidol, and saline in the prevention of postoperative nausea and vomiting after gynecological surgery. Anesth Analg 1997; 84: 662 -7 .

26. Capouet V, De Pauw C, Vernet B. Single dose i.v. Tropisetron in the prevention of postoperative nausea and vomiting after gynecological surgery. $\mathrm{Br} J$ Anaesth 1996; 76: 54-60.

27. Henzi I, Walder B, and Tramer M. Metoclopramide in the prevention of postoperative nausea and vomiting: a quantitative systemic review of randomized, placebo-controlled studies, BJA 1999;
83(5): 761-71.

28. Wilson E, Bass C. S, Abrameit W. Metoclopramide versus ondansetron in prophylaxis of nausea and vomiting for laparoscopic cholecystectomy, The American Journal of Surgery 2001; 181: 138141.

29. Quaynor $\mathrm{H}$ and reader J. Incidence and severity of postoperative nausea and vomiting are similar after Metoclopramide $20 \mathrm{mg}$ and ondansetron 25.8 $\mathrm{mg}$ given by the end of laparoscopic cholecystectomies, Acta Anaesthesiol Scand 2002; 46: 109113.

30. Nesek-Adam V, Grizelj-Stojcic E, Rasic Z, Comparison of Dexamethasone, Metoclopramide, and their combination in the prevention of postoperative nausea and vomiting after laparoscopic cholecystectomy, Surg Endosc 2007; 21: 607-612.

31. Nesek V, Grizelj E, Mrsic V. Prophylactic antiemetics for laparoscopic cholecystectomy: droperidol, Metoclopramide, and droperidol plus Metoclopramide, $\mathrm{J}$ of the laparoendoscopic \& advanced surgical techniques 2004; 14(4): 212-18.

32. Piper S, Suttner S, Rohm K. Dolasetron, but not Metoclopramide prevents nausea and vomiting in patients undergoing laparoscopic cholecystectomy, Can J anesth 2002; 49(10): 1021-1018.

33. Dabbagh A. Ali. A Comparative Study Between Dexamethasone, Meoclopramide, and Esmoprazole in the prevention of Postoperative Nausea and Vomiting after Laparoscopic Cholecystectomy, Zanco Journal of Medical Sciences 2008;12:55-62.

34. Wang J, Tai Ho Sh, Tzeng J, and Tang Ch, The effect of timing of Dexamethasone administration on its efficacy as a prophylactic antiemetic for postoperative nausea and vomiting, Anaesth Analg 2000; 91: 136-9.

35. Feo C, Sortini D, Ragazzi R. Randomized clinical trial of the effect of preoperative Dexamethasone on nausea and vomiting after laparoscopic cholecystectomy, British Journal of Surgery 2006; 93: 295-299. 